Article

\title{
On the Preservation of the Beak in Confuciusornis (Aves: Pygostylia)
}

\author{
Amanda Falk ${ }^{1}$, Jingmai $\mathrm{O}^{\prime}$ Connor ${ }^{2,3, *}{ }^{-}$, Min Wang ${ }^{2,3}$ and Zhonghe Zhou ${ }^{2,3, *}$ \\ 1 Biology Department, Centre College, 600 W. Walnut St. Danville, KY 40422, USA; amanda.falk@centre.edu \\ 2 Key Laboratory of Vertebrate Evolution and Human Origins of the Chinese Academy of Sciences, Institute of \\ Vertebrate Paleontology and Paleoanthropology, Beijing 100044, China; wangmin@ivpp.ac.cn \\ 3 CAS Center for Excellence in Life and Paleoenvironment, Beijing 10010, China \\ * Correspondence: jingmai@ivpp.ac.cn (J.O.); zhouzhonghe@ivpp.ac.cn (Z.Z.)
}

Received: 27 October 2019; Accepted: 10 November 2019; Published: 11 November 2019

\begin{abstract}
The Confuciusornithiformes represent the most stem-ward avian occurrence of an edentulous rostrum. Although a keratinous beak is widely considered to have covered the rostrum in confuciusornithiforms, this feature is almost never preserved, having been previously reported only in the holotype of Confuciusornis dui and the holotype of Eoconfuciusornis zhengi. This strongly contrasts with the widespread preservation of the keratinous sheaths that cover the manual and pedal ungual phalanges. Here, we report on a third occurrence of a preserved rhamphotheca in a specimen of Confuciusornis sanctus. We illuminated the preserved traces using laser-stimulated fluorescence. Similarly to $E$. zhengi, the rhamphotheca has been preserved only as a two-dimensional trace, whereas ungual sheaths are preserved in three dimensions. In contrast to the traces preserved in $C$. $d u i$, the rhamphotheca in the discussed specimen of $C$. sanctus is straight rather than upturned. This hints towards hidden morphological diversity within the thousands of Confuciusornis specimens, in which species may be further differentiated by soft tissue features or behaviors, much like many living birds, that cannot be detected in fossils, even with exceptional preservation.
\end{abstract}

Keywords: beak; rhamphotheca; Confuciusornithidae; Confuciusornithiformes; preservation; hidden diversity; Jehol biota

\section{Introduction}

The Confuciusornithiformes are the most common avian dinosaurs recovered in the Early Cretaceous Jehol biota. Thousands of specimens have reportedly been collected, most of which have been assigned to Confuciusornis sanctus and come from the 125 Ma Yixian formation [1]. The clade is represented by Eoconfuciusornis and an unnamed confuciusornithid in the 130.7 Ma Huajiying formation [2,3] and a few specimens of Confuciusornis have also been recovered from the $120 \mathrm{Ma}$ Jiufotang formation [4]. Confuciusornithiforms represent the oldest and most stem-ward documented avian occurrence of a pygostyle, a beak, and sexually dimorphic plumage [5]. Confuciusornithiforms are distinct from all currently recognized stem-avians (here referring to non-neornithine members of Aves) with regards to both skeletal and soft tissue morphologies, possessing an unusual and autopomorphic robust hand morphology [6,7] and a unique wing shape not found outside this group and with no modern counterpart [8]. Despite the wealth of specimens, none have preserved unequivocal indicators of diet [9], and confuciusornithiforms have been envisioned as herbivores based on their edentulous rostrum [10,11]; piscivores skimming fish from the surface of the lake in flight [12], based on the purported presence of fish bones in the eosophagus of one specimen [13]; and as sally-striking predators based on cranial morphology [14]. Pedal proportions suggest that confuciusornithiforms were generalists with regards to foraging ecology [15]. Histological studies 
suggest that confuciusornithiforms independently evolved higher growth rates $[16,17]$ in parallel to lineages of the Ornithuromorpha [5], the clade that includes Neornithes nested within.

One of the most notable morphological features of this clade is the bizarre, robust, akinetic diapsid skull with completely edentulous jaws $[6,10]$. The rostrum is considered to have been covered by a horny (keratinous) sheath called the rhamphotheca forming a beak, as in all neornithines (crown-group birds), based on the presence of numerous neurovascular foramina and grooves on the surface of the premaxilla and rostral portion of the dentaries $[6,18]$. The preservation of keratinous beaks in Jehol specimens is commonly cited as an example of the exceptional preservation of rare tissues $[19,20]$. However, only two specimens preserving traces of the rhamphotheca have been previously described: the holotype of Confuciusornis dui [10] and the holotype of Eoconfuciusornis zhengi [10]. In contrast, the horny sheath that covers the pedal claws is commonly preserved $[6,21]$. Here, we report on a third occurrence of beak preservation in a referred specimen of $C$. sanctus IVPP (Institute of Vertebrate Paleontology and Paleoanthropology, Beijing, China) V12352, originally the holotype of Jinzhouornis zhangjiyingia [1,22]. Although faintly visible to the naked eye, we illuminated these traces using laser-stimulated fluorescence (LSF) [23]. We described the traces, compared them to those in the holotype of $C$. $d u i$, and explored possible interpretations regarding beak morphology of confuciusornithiforms.

\section{Materials and Methods}

Confuciusornis sanctus IVPP V12352 was photographed using a Nikon D60 DSLR camera and a Nikkor AF-S 18-55 mm lens. Close-up photographs of the rhamphotheca were taken using a Nikkor AF-S Micro $85 \mathrm{~mm}$ macro lens. For LSF imaging, the specimen was photographed in a dark room (with minimal exposure to white light) using a $447 \mathrm{~nm} 300 \mathrm{~mW}$ blue laser and a MidOpt 470-52 light yellow long-pass filter, and a $532 \mathrm{~nm} 500 \mathrm{~mW}$ green laser and a MidOpt 550-52 orange long-pass filter following published methods [8,23]. A Thorlabs ED1-C20-MD $20^{\circ} 1$ inch diffuser was mounted on the end of the laser, spreading the light in a dotted square. Long-exposure shots were exposed for between 10 and $30 \mathrm{~s}$ (ISO value 800, aperture setting typically f-number of 13). Due to the length of the exposure, and the structure and pattern of light generated by the diffuser, the laser had to be moved slightly during the exposure. As a result, both camera and laser were mounted on individual tripods and placed on opposite sides of the specimen, in order to prevent the camera being jostled during photography.

\section{Results}

Confuciusornis sanctus IVPP V12352 is a nearly complete individual, preserved with partial articulation. The skull is excellently preserved and fully articulated in the left lateral view [1]. To the naked eye, the rhamphotheca is preserved as a dark colored two-dimensional stain on the matrix that surrounds the tip of the rostrum and is primarily visible on the premaxilla. These traces were more obviously visible under LSF, fluorescing red along with the bone (Figure 1). The traces of rhamphotheca terminate just rostral to the midpoint of the dorsal margin of the external nares. The rhamphotheca extends 6-7 $\mathrm{mm}$ beyond the tip of the rostrum. Just rostral to the tip of the premaxilla, the rhamphotheca traces have a maximum dorsal thickness of $2.8 \mathrm{~mm}$. Over the dorsal margin of the frontal processes of the premaxillae, the traces of the rhamphotheca have a maximum dorsoventral thickness of $0.9 \mathrm{~mm}$. The thickness of these traces steadily decreases caudally, truncating near the midpoint of the external nares. The tip of the rhamphotheca on the upper jaw appears to be slightly recurved ventrally. 

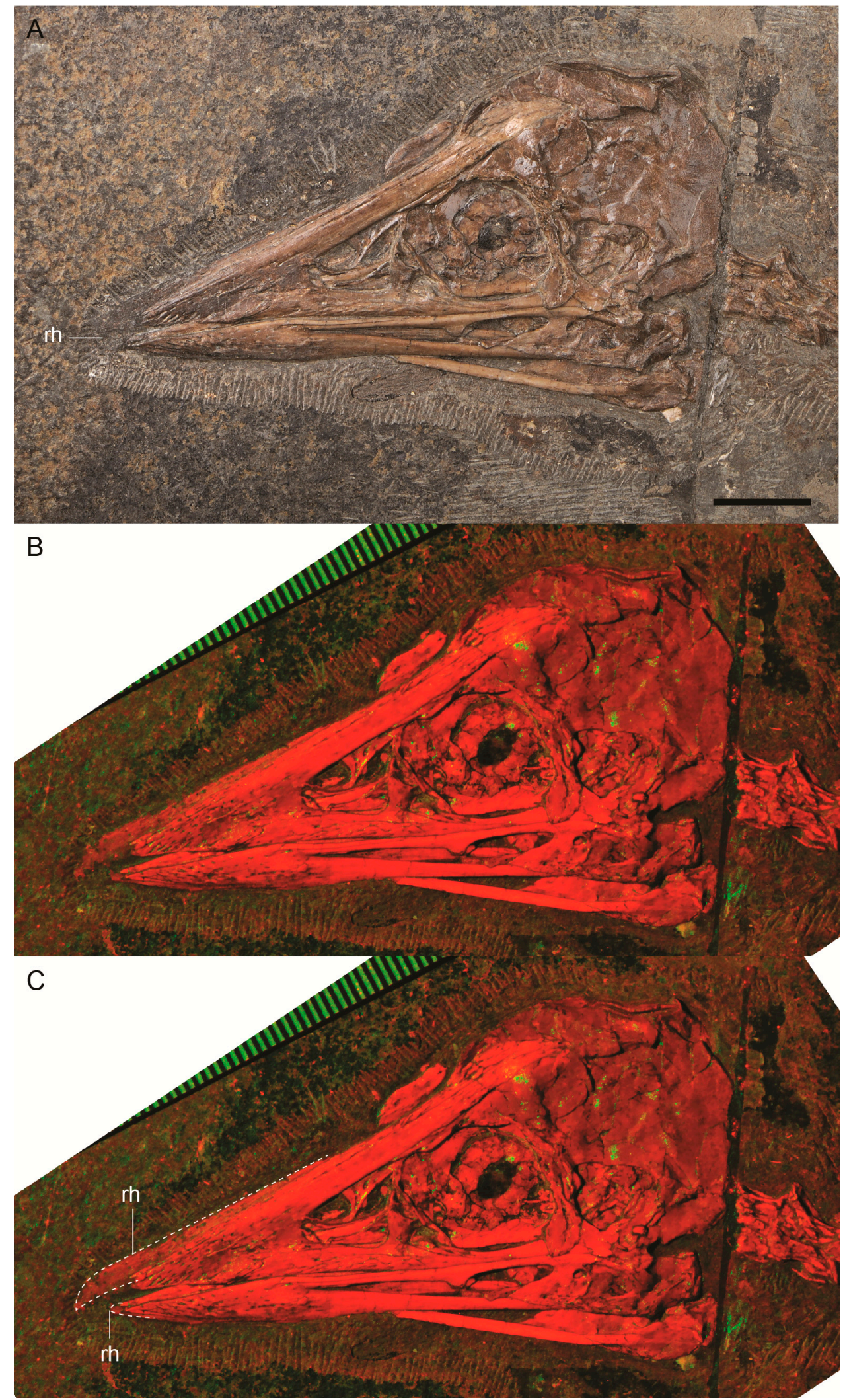

Figure 1. Photographs of Confuciusornis sanctus IVPP V12352 under (A) normal light (tip of upper keratinous beak indicated); and (B,C) laser-stimulated fluorescence (rhamphotheca of the upper and lower beak outlined in white dashed line). Anatomical abbreviations: rh—rhamphotheca. Scale bar equals $1 \mathrm{~cm}$. 
It appears that the rhamphotheca of the lower mandible experienced significant damage (as inferred from its jagged margins) during preparation and may be quite incomplete. Only a small portion of rhamphotheca has been visibly preserved, projecting $1.2 \mathrm{~mm}$ from the rostral tip of the mandible and extending a short distance along the ventral surface.

\section{Discussion}

An edentulous rostrum and, presumably, a keratinized sheath (rhamphotheca in birds) has evolved multiple times within the Dinosauria, including multiple origins among non-avian dinosaurs (e.g., oviraptorosaurs, ornithomimosaurs, ceratopsians) [24] as well as multiple origins within Aves (e.g., Confuciusornithiformes, Gobipteryx, Archaeorhynchus, Eogranivora) [9]. The repeated evolution of these features has been linked with increased cranial stability [25]. Despite the assumed presence of a keratinous beak in numerous lineages of edentulous dinosaurs, there is little direct evidence of this feature preserved in the fossil record. Among non-avian dinosaurs, direct evidence of a rhamphotheca is preserved in two ornithomimosaurs [26]. Confuciusornis sanctus IVPP V12352 is only the third Mesozoic bird found to have preserved remnants of the keratinous beak, and all known occurrences are in specimens that belong to the Confuciusornithiformes (Figure 2) [3,10]. Several other edentulous taxa co-exist in the Jehol biota (e.g., Archaeorhynchus, Eogranviora); however, these are known from far fewer specimens (five and one, respectively) which is probably why rhamphotheca has yet to be reported in these taxa, considering the rarity of these traces even in the Confuciusornithiformes, which are represented by thousands of specimens [27-31].
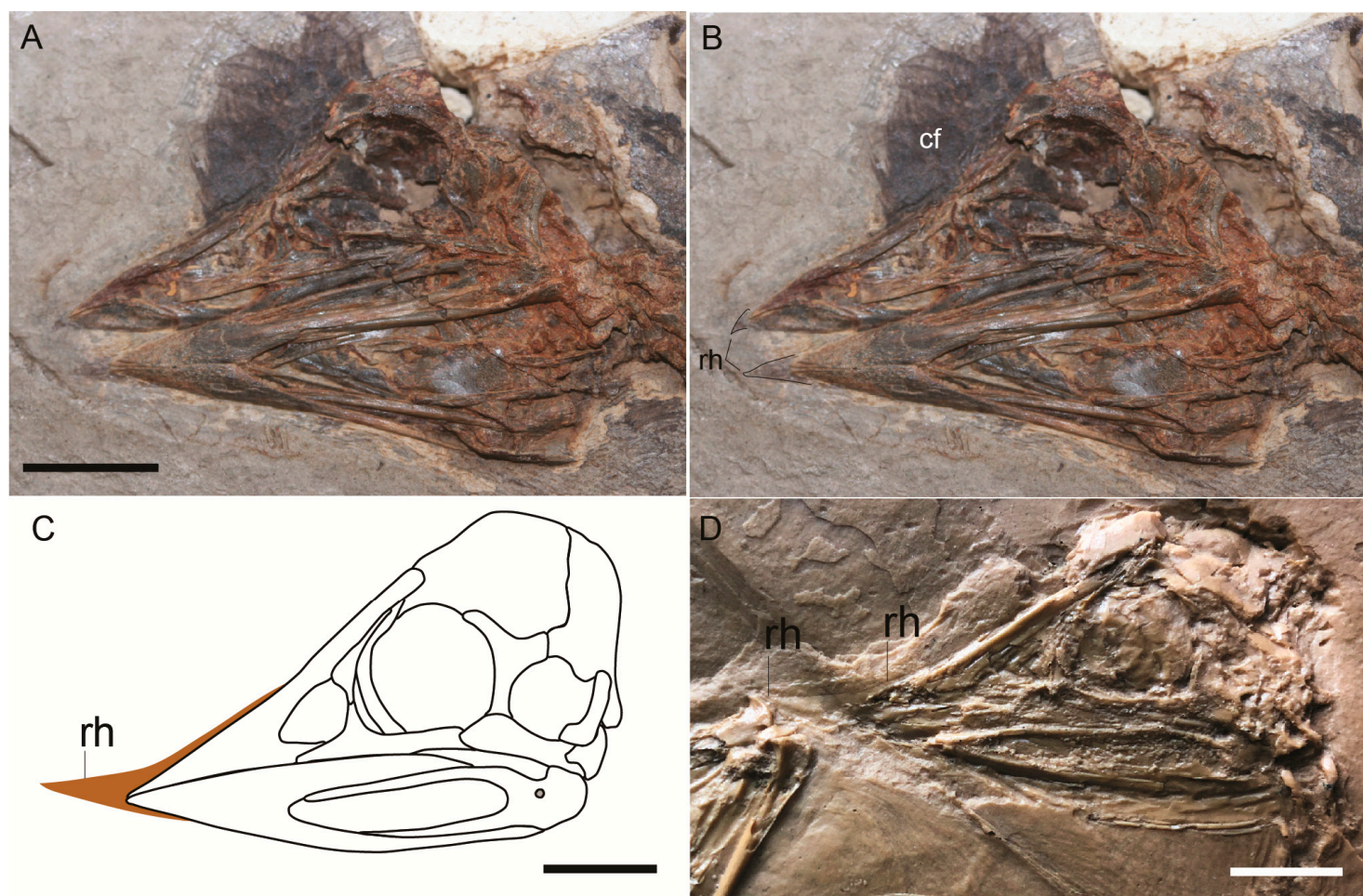

Figure 2. Other instances of rhampthotheca preservation in Mesozoic birds, which is at the time of publication only known to occur in the Confuciusornithiformes: $(\mathbf{A}, \mathbf{B})$ photograph of the skull of Eoconfuciusornis zhengi IVPP V11977; (C) line drawing of Confuciusornis dui IVPP V11553 drawn from Hou et al., 1999 (holotype and original photographs lost); (D) cast of Confuciusornis dui IVPP V11553-note the impression of the rhamphotheca is visible, suggesting the remnants were not entirely two-dimensional. Anatomical abbreviations not listed in Figure 1 caption: cf-coronal feathers. Scale bars equal $1 \mathrm{~cm}$. 
The traces of the rhamphotheca described here are represented only by a dark stain mostly associated with the premaxilla, offering no information regarding the three-dimensional morphology of the keratinous beak itself. The lateral extent of the rhamphotheca across the dentary, premaxilla, and potentially also the maxilla cannot be determined directly from the preservation in these two specimens or with available techniques. It is likely that any traces that covered the bones were lost during preparation. Although some researchers have suggested that the extent of the rhamphotheca can be inferred by the number of foramina on the lateral surface of these elements, this is still controversial [32]. In light of the rarity of direct traces, even the small amounts of information preserved offer insights into the beak morphology of confuciusornithiforms. The traces preserved in the holotype of C. dui IVPP V11553 are similar in size to those preserved in C. sanctus IVPP V12352, despite differences in overall body size (IVPP V11553 is 80\% the size of V12352 according to femoral length). Notably, the overall shape of the impression is also very different in each specimen. Unfortunately, IVPP V11553 has been misplaced and is not available for measurements, which thus had to be taken from the published photographs $[1,10]$ and a cast. Surprisingly, the traces of the rhamphotheca were visible in the cast, suggesting that, unlike the traces in IVPP V12352, the remnants in IVPP V11553 were somewhat three-dimensional (Figure 2c).

The caudal preserved extent of the rhamphotheca is similar in both specimens, ending cranial to the caudal margin of the external nares, and ending approximately near the midpoint of the nares. Interestingly, the beak impression reported in a specimen of Ornithomimus also extends to the same level, although due to the rostral position of the external nares in ornithomimids, the beak is much more limited in this clade [26]. In E. zhengi IVPP V11977, the rhamphotheca is only visible where it extends rostral to the premaxilla (Figure 2a), but in this specimen and in the referred specimen STM (Shandong Tianyu Museum of Nature, Pingyi, China) 7-144, which does not have preserved traces of the rhamphotheca, coronal feathers are preserved that extend rostrally to the same point, supporting interpretations regarding the caudal extent of the keratinized beak $[3,5]$. The thickness of the rhamphotheca, measured where it extends dorsally over the frontal processes of the premaxilla, measures $0.9 \mathrm{~mm}$ in IVPP V12352 and 0.6 in IVPP V11553. These values are very close to the average thickness $(0.7442 \mathrm{~mm})$ of the rhamphotheca reported in extant birds [33]. In addition, the rhamphotheca preserved in both IVPP V12352 and IVPP V11553 extends cranially from the tip of the rostrum for approximately the same distance (6-7 $\mathrm{mm}$ in IVPP V12352, compared to $6.8 \mathrm{~mm}$ measured from the publication and $7.9 \mathrm{~mm}$ measured from the cast in IVPP V11553). The maximum dorsoventral thickness of the rhampthotheca is the same in the two specimens (2.8 mm in IVPP V12352 and V11553). The consistency between these two specimens with regards to these proportions is unusual, considering the considerable size difference between them (femoral length $41.9 \mathrm{~mm}$ in IVPP V12352 vs. $33.8 \mathrm{~mm}$ in V11553). In the older and more basal E. zhengi, the rhamphotheca preserved in IVPP V11977 (femur length $35 \mathrm{~mm}$ ) is much shorter, extending only $1.3 \mathrm{~mm}$ (measured from the publication) from the tip of the premaxilla. With such a small sample size, there is no way to elucidate the cause of this variation; it may reflect interspecific differences related to function, ontogeny (the rhamphotheca elongates during early ontogeny in some neornithines), or seasonal changes in beak size, with the proportionately larger rhamphotheca of IVPP V12352 capturing a period in which the beak was at its maximum length and the shorter rhamphotheca in IVPP V11553 and V11977 preserving a seasonal minimum [33-35].

The two Confuciusornis specimens differ in the shape of the portion of the rhamphotheca located cranial to the bony rostrum. In C. dui IVPP V11553 the traces of the rhamphotheca are distinctly dorsally recurved, forming a sharply tapered rostral tip (Figure 2b) [10], whereas the dorsal margin of the rhamphotheca is nearly straight in IVPP V12352 (Figure 1). The tip of the rhamphotheca appears to be slightly hooked ventrally in both C. sanctus IVPP V12352 and E. zhengi IVPP V11977. These differences may represent adaptations for specific foraging techniques [36]. Notably, the three specimens preserving rhamphotheca traces all represent different taxa (C. sanctus IVPP V12352, C. dui IVPP V11553, and E. zhengi IVPP V11977) that have been upheld after rigorous re-examination [1]. This suggests that these different species may have relied on different resources. However, associating 
this variation in shape with a specific diet is difficult, since it has been shown that beak shape and diet do not correlate as well as previously hypothesized [37,38]. Although these studies focused on the morphology of the bony core of the beak rather than the rhamphotheca itself, the rhamphotheca is generally shaped by the underlying bones $[33,39]$ although there are notable exceptions such as shrikes, in which the ventrally hooked tip of the rhamphotheca is absent in the premaxilla (G. Navalón personal communication). Notably, the upturned morphology of the rhamphotheca of the upper jaw in C. dui IVPP V11553 does not appear to be a morphology commonly utilized by extant neornithines [36,37].

The widespread absence of preserved traces of the rhamphotheca has led to the hypothesis that the rhamphotheca in confuciusornithiforms was soft and flexible, similar to that of ducks and other waterfowl $[39,40]$, which is seemingly inconsistent with the morphology-based observation that the skull is well-suited for load bearing [12]. Based on comparison with neornithine birds preserved in the Eocene Messel Pit Lagerstätte in Germany, O'Connor (2019) concluded that the infrequent preservation of rhamphotheca in confuciusornithiforms (and all other beaked archosaurs) is unrelated to relative hardness, but rather reflects that the rhamphotheca is a feature that is rarely preserved in either stem or crown birds. It is possible that the limited preservation of the rhamphotheca is due to post-mortem loss. Indeed, in skeletal specimens in collections, the rhamphotheca often flakes off (J.O'Connor pers. obs.) and is not preserved [37]. However, this flaking is due to dehydration, which is not a factor in aquatic depositional environments like those that yielded the Jehol biota. In one study of bird decay, loss of the rhamphotheca was not mentioned [41]. However, the fully articulated and largely complete (including small elements like the hyoid bones) preservation of most Jehol birds indicates that these carcasses did not undergo extensive decay before stabilization through burial, inconsistent with loss of the rhamphotheca due to disarticulation.

In comparison, the keratinous sheaths that envelope the manual and pedal unguals are commonly preserved [6,42-44]. Feathers, like beaks and claws, are also formed of $\beta$-keratin and are commonly preserved in the Jehol biota [45]. Studies on extant avian integument indicate that the $\beta$-keratin monomers forming beaks and claws measure 14,500-15,500 daltons, forming structures that are rigid and stiff, whereas those of feathers measure 10,500 daltons, the lower molecular mass reflecting a much more flexible structure $[45,46]$. Additional studies have shown that the $\beta$-keratin forming the beak is harder than that forming the claws, which is in turn harder than that forming the feathers [47]. The fossil record is overwhelmingly dominated by hard tissues. However, the results of these studies on the properties of various $\beta$-keratin structures are inconsistent with the common preservation of claws and feathers over beaks in the Jehol biota. One conclusion is that the preservation of these keratinous structures is not linked to hardness. Preservation of keratin structures may not be related to intrinsic properties of the structures themselves, but rather affected by the taphonomic chemical microenvironment unique to each specimen. This is supported by the fact that the beak and feathers have been preserved in E. zhengi IVPP V11977 but not the keratinous sheaths of the claws, whereas $C$. sanctus IVPP V12352 has preserved beak and claw sheaths, but not feathers. In the case of feathers, it is often the decay-resistant melanosomes that are preserved, rather than the keratin matrix [48]. However, this still does not explain the common preservation of claws and the rarity of beak traces in Jehol deposits. At this time, there is no obvious pattern in the preservation of keratinous epidermal structures that might shed light on these inconsistencies.

Author Contributions: Conceptualization, J.O., A.F., M.W. and Z.Z.; methodology, A.F.; investigation, A.F. and J.O.; resources, Z.Z.; writing-original draft preparation, J.O., A.F., M.W.; writing-review and editing, J.O.; funding acquisition, Z.Z.

Funding: This research was funded by National Natural Science Foundation of China grant number 41688103.

Acknowledgments: We thank two reviewers for comments on an earlier version of this manuscript.

Conflicts of Interest: The authors declare no conflict of interest. 


\section{References}

1. Bonser, R.H. Comparative mechanics of bill, claw and feather keratin in the Common Starling Sturnus vulgaris. J. Avian Biol. 1996, 27, 175-177. [CrossRef]

2. Bright, J.A.; Marugán-Lobón, J.; Cobb, S.N.; Rayfield, E.J. The shapes of bird beaks are highly controlled by nondietary factors. Proc. Natl. Acad. Sci. USA 2016, 113, 5352-5357. [CrossRef] [PubMed]

3. Brush, A.H.; Wyld, J.A. Molecular organization of avian epidermal structures. Comp. Biochem. Physiol. 1982, 73, 313-325. [CrossRef]

4. Button, K.A. Soft Tissue Reconstruction and Ecomorphology of Beaks in Extant and Extinct Theropod Dinosaurs; North Carolina State University: Raleigh, NC, USA, 2018.

5. Chiappe, L.M.; Ji, S.; Ji, Q.; Norell, M.A. Anatomy and systematics of the Confuciusornithidae (Theropoda: Aves) from the Late Mesozoic of northeastern China. Bull. Am. Mus. Nat. Hist. 1999, 242, 1-89.

6. Cuff, A.R.; Rayfield, E.J. Retrodeformation and muscular reconstruction of ornithomimosaurian dinosaur crania. PeerJ 2015, 3, e1093. [CrossRef] [PubMed]

7. Dalsätt, J.; Zhou, Z.; Zhang, F.; Ericson, P.G.P. Food remains in Confuciusornis sanctus suggest a fish diet. Naturwissenschaften 2006, 93, 444-446. [CrossRef] [PubMed]

8. Davis, P.G.; Briggs, D.E.G. The impact of decay and disarticulation on the preservation of fossil birds. Palaios 1998, 13, 3-13. [CrossRef]

9. De Ricqlès, A.J.; Padian, K.; Horner, J.R.; Lamm, E.T.; Myhrvold, N. Osteohistology of Confuciusornis sanctus (Theropoda: Aves). J. Vertebr. Paleontol. 2003, 23, 373-386. [CrossRef]

10. Elzanowski, A.; Peters, D.S.; Mayr, G. Cranial morphology of the Early Cretaceous bird Confuciusornis. J. Vertebr. Paleontol. 2018, 38, e1439832. [CrossRef]

11. Falk, A.R.; Kaye, T.G.; Zhou, Z.H.; Burnham, D.A. Laser Fluorescence Illuminates the Soft Tissue and Life Habits of the Early Cretaceous Bird Confuciusornis. PLoS ONE 2016, 11, e0167284. [CrossRef] [PubMed]

12. Greenberg, R.; Etterson, M.; Danner, R.M. Seasonal dimorphism in the horny bills of sparrows. Ecol. Evolut. 2013, 3, 389-398. [CrossRef] [PubMed]

13. Homberger, D.G.; Brush, A.H. Functional-morphological and biochemical correlations of the keratinized structures in the African Grey Parrot, Psittacus erithacus (Aves). Zoomorphology 1986, 106, 103-114. [CrossRef]

14. Hopson, J.A. Ecomorphology of avian and nonavian theropod phalangeal proportions: Implications for the arboreal versus terrestrial origin of bird flight. In New Perspectives on the Origin and Early Evolution of Birds; Gauthier, J., Gall, L.F., Eds.; Peabody Museum of Natural History: New Haven, CT, USA, 2001; pp. 211-235.

15. Hou, L.; Martin, L.D.; Zhonghe, Z.; Feduccia, A.; Zhang, F. A diapsid skull in a new species of the primitive bird Confuciusornis. Nature 1999, 399, 679-682. [CrossRef]

16. Hou, L.; Zhou, Z.; Gu, Y.; Zhang, H. Confuciusornis sanctus, a new Late Jurassic sauriurine bird from China. Chin. Sci. Bull. 1995, 40,1545-1551.

17. Hou, L.; Zhou, Z.; Zhang, F.; Gu, Y. Mesozoic Birds from Western Liaoning in China; Liaoning Science and Technology Publishing House: Liaoning, China, 2002.

18. Hu, H.; O'Connor, J.K. First species of Enantiornithes from Sihedang elucidates skeletal development in Early Cretaceous enantiornithines. J. Syst. Palaeontol. 2017, 15, 909-926. [CrossRef]

19. Kaye, T.G.; Falk, A.R.; Pittman, M.; Sereno, P.C.; Martin, L.D.; Burnham, D.A.; Gong, E.P.; Xu, X.; Wang, Y.N. Laser-Stimulated Fluorescence in Paleontology. PLoS ONE 2015, 10, e0125923. [CrossRef] [PubMed]

20. Lautenschlager, S.; Witmer, L.M.; Altangerel, P.; Rayfield, E.J. Edentulism, beaks, and biomechanical innovations in the evolution of theropod dinosaurs. Proc. Natl. Acad. Sci. USA 2013, 110, 20657-20662. [CrossRef] [PubMed]

21. Li, L.; Wang, J.Q.; Hou, S.L. A new species of Confuciusornis from Lower Cretaceous of Jianchang, Liaoning, China. Glob. Geol. 2010, 29, 183-187.

22. Lovette, I.J.; Fitzpatrick, J.W. The Handbook of Bird Biology, Cornell Lab of Ornithology; Princeton University Press: Princeton, NJ, USA, 2004.

23. Matthysen, E. Seasonal variation in bill morphology of Nuthatches Sitta europaea: Dietary adaptations or consequences? Ardea 1989, 77, 117-125.

24. Navalón, G.; Bright, J.A.; Marugán-Lobón, J.; Rayfield, E.J. The evolutionary relationship among beak shape, mechanical advantage, and feeding ecology in modern birds. Evolution 2019, 73, 422-435. [CrossRef] [PubMed] 
25. Navalón, G.; Meng, Q.J.; Marugán-Lobón, J.; Zhang, Y.G.; Wang, B.P.; Xing, H.; Liu, D.; Chiappe, L.M. Diversity and evolution of the Confuciusornithidae: Evidence from a new 131-million-year-old specimen from the Huajiying Formation in NE China. J. Asian Earth Sci. 2018, 152, 12-22. [CrossRef]

26. Norell, M.A.; Makovicky, P.J.; Currie, P.J. The beaks of ostrich dinosaurs. Nature 2001, 412, 873-874. [CrossRef] [PubMed]

27. Norell, M.A.; Xu, X. Feathered dinosaurs. Annu. Rev. Earth Planet. Sci. 2005, 33, 277-299. [CrossRef]

28. O'Connor, J.K.; Wang, X.R.; Chiappe, L.M.; Gao, C.H.; Meng, Q.J.; Cheng, X.D.; Liu, J.Y. Phylogenetic support for a specialized clade of Cretaceous enantiornithine birds with information from a new species. J. Vertebr. Paleontol. 2009, 29, 188-204. [CrossRef]

29. O'Connor, J.K. The trophic habits of early birds. Palaeogeogr. Palaeoclimatol. Palaeoecol. 2019, 513, $178-195$. [CrossRef]

30. Olsen, A.M. Feeding ecology is the primary driver of beak shape diversification in waterfowl. Funct. Ecol. 2017, 31, 1985-1995. [CrossRef]

31. Peters, D.S. Das exponat des Monats: Ein nahezu vollständiges Skelett eines urtümlichen vogels aus China. Nat. Mus. 1996, 126, 298-302.

32. Stettenheim, P.R. The integumentary morphology of modern birds-An overview. Am. Zool. 2000, 40, 461-477. [CrossRef]

33. Wang, M.; O'Connor, J.K.; Zelenkov, N.Z.; Zhou, Z.H. A new diverse enantiornithine family (Bohaiornithidae fam. nov.) from the Lower Cretaceous of China with information from two new species. Vertebr. Palasiat. 2014, 52, 31-76.

34. Wang, M.; O'Connor, J.; Zhou, Z.H. A taxonomical revision of the Confuciusornithiformes (Aves: Pygostylia). Vertebr. Palasiat. 2019, 57, 1-37.

35. Wang, M.; Zhou, Z.H. A new adult specimen of the basalmost ornithuromorph bird Archaeorhynchus spathula (Aves: Ornithuromorpha) and its implications for early avian ontogeny. J. Syst. Palaeontol. 2016, 15, 1-18. [CrossRef]

36. Wang, M.; Zhou, Z.H. A new confuciusornithid (Aves: Pygostylia) from the Early Cretaceous increases the morphological disparity of the Confuciusornithidae. Zool. J. Linn. Soc. 2018, 185, 417-430. [CrossRef]

37. Wang, X.L.; O'Connor, J.; Maina, J.N.; Pan, Y.H.; Wang, M.; Wang, Y.; Zheng, X.T.; Zhou, Z.H. Archaeorhynchus preserving significant soft tissue including probable fossilized lungs. Proc. Natl. Acad. Sci. USA 2018, 115, 11555-11560. [CrossRef] [PubMed]

38. Weishampel, D.B.; Dodson, P.; Osmolska, H. The Dinosauria; University of California Press: Berkeley, CA, USA, 2004.

39. Zhang, F.; Hou, L.; Ouyang, L. Osteological microstructure of Confuciusornis: Preliminary report. Vertebr. Pal Asiat. 1998, 36, 126-135.

40. Zhang, F.; Zhou, Z.; Benton, M.J. A primitive confuciusornithid bird from China and its implications for early avian flight. Sci. China Ser. D 2008, 51, 625-639. [CrossRef]

41. Zhang, F.C.; Kearns, S.L.; Orr, P.J.; Benton, M.J.; Zhou, Z.H.; Johnson, D.; Xu, X.; Wang, X.L. Fossilized melanosomes and the colour of Cretaceous dinosaurs and birds. Nature 2010, 463, 1075-1078. [CrossRef] [PubMed]

42. Zheng, X.T.; O'Connor, J.K.; Wang, X.L.; Pan, Y.H.; Wang, Y.; Wang, M.; Zhou, Z.H. Exceptional preservation of soft tissue in a new specimen of Eoconfuciusornis and its biological implications. Natl. Sci. Rev. 2017, 4, 441-452. [CrossRef]

43. Zheng, X.T.; O'Connor, J.K.; Wang, X.L.; Wang, Y.; Zhou, Z.H. Reinterpretation of a previously described Jehol bird clarifies early trophic evolution in the Ornithuromorpha. Proc. R. Soc. B 2018, 285, 20172494. [CrossRef] [PubMed]

44. Zhou, S.; Zhou, Z.H.; O'Connor, J.K. Anatomy of the Early Cretaceous Archaeorhynchus spathula. J. Vertebr. Paleontol. 2013, 33, 141-152. [CrossRef]

45. Zhou, Z.; Barrett, P.M.; Hilton, J. An exceptionally preserved Lower Cretaceous ecosystem. Nature 2003, 421, 807-814. [CrossRef] [PubMed]

46. Zhou, Z.; Zhang, F. Anatomy of the primitive bird Sapeornis chaoyangensis from the Early Cretaceous of Liaoning, China. Can. J. Earth Sci. 2003, 40, 731-747. [CrossRef] 
47. Zhou, Z.H.; Zhang, F.C. A beaked basal ornithurine bird (Aves, Ornithurae) from the Lower Cretaceous of China. Zool. Scr. 2006, 35, 363-373. [CrossRef]

48. Zinoviev, A.V. An attempt to reconstruct the lifestyle of confuciusornithids (Aves, Confuciusornithifomes). Paleontol. J. 2009, 43, 444-452. [CrossRef] article distributed under the terms and conditions of the Creative Commons Attribution (CC BY) license (http://creativecommons.org/licenses/by/4.0/). 